\title{
Turkey Handwashing Survey: suggestion for taking the ecological model into better consideration
}

\author{
Hakan Tüzün $^{1}$ Kağan Karakaya ${ }^{1} \cdot$ Emine Baran Deniz $^{1}$
}

Received: 22 April 2015/ Accepted: 12 May 2015/Published online: 23 May 2015

(C) The Japanese Society for Hygiene 2015

\begin{abstract}
Objectives This study is aimed to find out the handwashing habits and their relations to the socio-economic variables.

Methods The sampling is determined regarding the address-based population registration system of the country. The multi-staged stratified cluster sampling method was used. It is conducted by a face to face questionnaire with 6854 persons. 22 questions are asked whether they are washing their hands or not related to different situations, the results are graded and the "Handwashing Habits Score" (HHS) is obtained. The reasons for not handwashing were evaluated by categorizing as individual, environmental and combined reasons.

Results The HHS is increasing in the older age groups $(\beta=0.148, p<0.001)$, females $(\beta=0.306, p<0.001)$, citizens of urban settlement $(\beta=0.061, p<0.001)$, higher education levels $(\beta=0.191, p<0.001)$. The reasons for not handwashing were found as $53.3 \%$ individual, $39.2 \%$ environmental, $7.5 \%$ combined. The frequency of mentioning not washing hands because of the environmental reasons is getting higher in the older age groups, in the urban side, and in the higher education level $(p<0.001)$. Conclusions The handwashing habits are shaped by the determinant networks which form a complex structure by intertwining individual, socio-economic and environmental factors in different sub-groups with various weights. This
\end{abstract}

Hakan Tüzün

drtuzunh@yahoo.com

1 Republic of Turkey, Ministry of Health, General Directorate of Health Promotion, Türkiye Halk Sağlığı Kurumu K Blok. Sihhiye, 06410 Ankara, Turkey result might contribute to the efforts of conceptualizing the health behaviors with ecological model.

Keywords Handwashing - Environmental factors · Ecological model · Health determinants · Turkey

\section{Introduction}

The lower respiratory diseases and diarrhea are taking part on the first two lines of the disease burden distribution leading to death worldwide [1]. Pneumonia and diarrhea account for $29 \%$ of all deaths of children less than 5 years of age and result in the loss of 2 million young lives each year [2]. There are many studies showing that specifically the improvement of handwashing is decreasing substantially the diarrhea morbidity [3-7]. The handwashing is one of the primary prevention not only from the oral fecal diseases but also from the respiratory infected diseases $[4$, $6,8-10]$.

The handwashing frequencies studies have resulted that the frequencies are not on the desired levels [11-13]. For example, the frequency of the handwashing after the toilet is among the 11 underdeveloped and developing countries is $3 \%$ (Ghana) and $42 \%$ (India). The handwashing studies among the developed countries can sometimes not reach to the desired points, a study made in England has resulted that the $65 \%$ of the females and $31 \%$ of the males are washing hands after the toilet [14].

Although the basic role in preventing the infected diseases is well known, the hygiene behaviors have a sophisticated structure including the need and the convenience to the social values. Therefore, the hygiene promotion studies have to determine the core meanings of the hygiene behaviors and to define the specific behaviors carrying risks 
for the health [15]. It is stated that the socio-economic and cultural determinants should be taken into consideration for the intervention studies to obtain effective behavior change results [16]. The studies investigating the socio-economic determinants in relation with handwashing habits show that economic level, education level, gender, the opportunities reaching the water and settlements are variables in relation with handwashing frequency [17-21].

The handwashing behaviors surveys conducted in Turkey are generally the studies within the scope of school health [22-27]. The examples of the population-based studies, on the other hand, are local studies directed to chosen special groups [28, 29]. In Turkey, new evidences, obtained from studies based on the population to point out the possible intervention points by assigning the individual, socio-economic and environmental determinants, are required. The "Turkey Handwashing Survey" which has the first research characteristic of national handwashing habits, is aimed to find out the handwashing habits and their relations to the socio-economic variables.

\section{Materials and methods}

\section{Sampling}

The sampling of the study is determined by TurkStat (Turkey Statistical Institute) according to APRS (Addressbased Population Registration System). APRS is a database in which all the house addresses are recorded in national level. As the sample method, the multi-staged stratified cluster sampling method was used. On the first stage, the groups, on the second stage, the households selected from the groups were selected. The stratifying was made regarding the settlements; according to the settlements for stratifying the variables "urban/rural" was used. For the urban settlements and the rural settlements having a municipality, the grouping was made by TurkStat after taking into consideration 100 addresses for each group, the rural settlement without municipality was taken into consideration as one group. The groups were selected regarding the systematic sampling method. The households were selected from each selected group within the systematic sampling method. From the urban settlements were selected 243 group and from each group 15 households and that made totally 3645 household, and from the rural settlements 96 group and from each of them 15 households were selected and that made totally 1440 household samplings.

\section{Implementation}

By forming the questionnaire, it was benefited from the questions of a data collecting survey, which are used for a study of determining the handwashing information and behaviors and the relation to their sociodemographic characteristics of persons who applied to a health center in Ankara during 5 work days [30].

Before the interview, information about the study was given to the person and informed consent was taken as oral from them. For less than 18 years old informed consent of the relatives were taken over. Ethical Committee evaluates the studies according to the "Regulation on Drug and Biological Products' Clinical Researches" in Turkey. This study is out of this regulation.

The data collection stage of the study was practiced by the local health authorities on March 2009. A questionnaire was administered to everyone who is over 12 years of age and who live in that house and accept to participate into the study with face to face method. Thus, the study was performed with 6854 people in total, by reaching to 3672 of 5085 houses $(72.2 \%)$.

\section{Classification of variables and statistical method}

To determine the handwashing habits, there are 22 questions asked whether they are washing their hands or not by different situations (before the meals, after the meals, before the toilet, after the toilet, coming home, after shaking hands, before going to sleep, after touching the animals, waking up in the morning, after changing diaper, before eating anything, seeing their hands dirty, before preparing meals, after exchanging money, after blowing your nose, after touching the trash, before touching a sick person, after touching a sick person, after combing your hair, after cleaning the house, after diswashing, after doing laundry). The answers to the questions were graded as "never" 0 , "rarely" 1, "sometimes" 2, "mostly" 3, "always" 4. The grades were collected for 22 questions and a "Handwashing Habits Score" (HHS) was obtained. A linear regression model was formed for HHS.

The participants were classified for the before meals and after the toilet cases, specifically, as the ones who always handwash and the ones who never, rarely, sometimes and mostly handwash and logistic regression models were formed for those two handwashing behavior.

The reasons of the cases when the participants thought that they should handwash but they do not were questioned. The reasons for not handwashing were grouped to examine the reasons of not handwashing according to some determinant variables with Chi-square test. The ones who indicated one or more of the individual reasons were grouped as individual reason, the ones who indicated one or more of the environmental reasons were grouped as environmental reasons and the ones who indicated one of individual or environmental reasons together were grouped as combined reason. 
Table 1 Logistic regression analysis for variables predicting always washing hands before the meals and always washing hands after the toilet

\begin{tabular}{|c|c|c|c|c|}
\hline & $\begin{array}{l}\text { Always washing hands } \\
\text { before the meals }(\%)\end{array}$ & OR $(95 \%$ CI $)$ & $\begin{array}{l}\text { Always washing hands } \\
\text { after the toilet }(\%)\end{array}$ & OR $(95 \% \mathrm{CI})$ \\
\hline \multicolumn{5}{|l|}{ Age group } \\
\hline $12-20$ & 48.9 & 1.00 & 87.5 & 1.00 \\
\hline $21-30$ & 56.8 & $1.327(1.118-1.574)$ & 90.3 & $1.223(0.932-1.605)$ \\
\hline $31-40$ & 63.7 & $1.910(1.602-2.277)$ & 92.2 & $1.732(1.298-2.312)$ \\
\hline $41-50$ & 66.2 & $2.337(1.941-2.815)$ & 92.6 & $2.077(1.526-2.828)$ \\
\hline $51-60$ & 65.8 & $2.490(2.043-3.034)$ & 93.2 & $2.585(1.844-3.624)$ \\
\hline $61-70$ & 68.4 & $3.162(2.514-3.977)$ & 93.0 & $2.962(2.003-4.378)$ \\
\hline $71-80$ & 63.6 & $2.927(2.221-3.858)$ & 90.4 & $2.462(1.584-3.827)$ \\
\hline 81 and above & 63.0 & $2.836(1.705-4.717)$ & 80.8 & $1.076(0.566-2.046)$ \\
\hline \multicolumn{5}{|l|}{ Sex } \\
\hline Male & 57.5 & 1.00 & 90.0 & 1.00 \\
\hline Female & 63.1 & $1.521(1.364-1.696)$ & 91.8 & $1.665(1.385-2.002)$ \\
\hline \multicolumn{5}{|l|}{ Settlement } \\
\hline Rural & 59.0 & 1.00 & 90.7 & 1.00 \\
\hline Urban & 62.4 & $1.042(0.939-1.157)$ & 91.4 & $0.895(0.750-1.068)$ \\
\hline \multicolumn{5}{|l|}{ Education level } \\
\hline No education & 53.5 & 1.00 & 85.5 & 1.00 \\
\hline Primary incomplete & 59.2 & $1.466(1.170-1.836)$ & 90.0 & $1.868(1.314-2.657)$ \\
\hline First level primary & 62.8 & $1.982(1.687-2.328)$ & 91.8 & $2.589(2.025-3.311)$ \\
\hline Second level primary & 57.7 & $2.331(1.893-2.870)$ & 89.8 & $2.908(2.112-4.005)$ \\
\hline High school & 63.4 & $2.551(2.081-3.128)$ & 94.4 & $5.065(3.553-7.221)$ \\
\hline College/university & 70.9 & $3.302(2.551-4.273)$ & 96.3 & $7.276(4.241-12.481)$ \\
\hline
\end{tabular}

The statistically significant level is accepted as $p<0.05$.

\section{Results}

The average age of the persons is 39.9 (SD 17.7). Within the scope of the study, the $63.6 \%$ of the persons are female and $36.4 \%$ male. The $61.6 \%$ of the interviewed persons are from urban and $38.4 \%$ from rural. If we take a look to the education level distribution, the first place is consisting of the primary education $(42.0 \%)$, this is followed closely by the high school $(15.1 \%)$, second primary school $(14.6 \%)$ and primary incomplete $(14.5 \%)$.

Within the situations where the hands are always washed, after the toilet ( $91.1 \%)$, waking up in the morning $(85.7 \%)$, after touching trash $(83.5 \%)$, after cleaning the nose $(83.1 \%)$ are placed on the top.

The $78 \%$ of the interviewed persons are thinking that the handwashing has a very high importance for prevention from the diseases, $20.5 \%$ of them are thinking that it is very important, $1.2 \%$ important and $0.4 \%$ less important.

The frequency of always handwashing after the toilet throughout the country is $91.1 \%$. The frequency of always handwashing before the meals is throughout the country
$61.1 \%$. According to the logistic regression model, the possibility to handwash before meals and after the toiled is higher in other age groups when compared to 12-20 age group. Generally, the possibility of both handwashing behavior increases with increasing education level. According to the model, handwashing possibility is higher in women both before the meals (OR 1.521, $95 \%$ CI 1.364-1.696) and after the toilet (OR 1.665, $95 \%$ CI 1.385-2.002). On the other hand, it was seen that there is no effect of settlement on determination of this handwashing behavior (Table 1).

According to the results of the linear regression model, the HHS is increasing in the older age groups $(\beta=0.148$, $p<0.001)$, in the females $(\beta=0.306, p<0.001)$, in the citizens of urban settlement $(\beta=0.061, p<0.001)$ and in increasing education levels $(\beta=0.191, \quad p<0.001)$ (Table 2).

The $30.9 \%$ of the people living in urban settlement are placing the reason; to forget, than $29.8 \%$ not having the proper place or tap for handwashing, $22.0 \%$ not to find time, while the $39.0 \%$ of the people in the rural are placing the reason to not having time and then the $39.0 \%$ to forget, the $28.6 \%$ not having the proper place or tap for handwashing and the $27.8 \%$ not to have time (Table 3).

Considering the whole interviewed people, it is seen that the $53.3 \%$ of them according to the individual 
Table 2 The linear regression model of some variances influences of HHS

\begin{tabular}{llr}
\hline & $\beta^{\mathrm{a}}$ & $p$ \\
\hline Age group (12-20, 21-30, 31-40, 41-50, 51-60, 61-70, 71-80, 81 and above) & 0.148 & $<0.001$ \\
Sex (male, female) & 0.306 & $<0.001$ \\
Settlement (rural, urban) & 0.061 & $<0.001$ \\
Education level (NE, PI, FLP, SLP, HS, C-U) & 0.191 & $<0.001$ \\
Model & & $<0.001$ \\
\hline
\end{tabular}

$N E$ no education, $P I$ primary incomplete, FLP first level primary, SLP second level primary, $H S$ high school, $C-U$ college/university

a Standardized $\beta$ values were used

Table 3 The percentage distribution of the interviewed persons according to the reasons why they are not washing their hands

\begin{tabular}{lccc}
\hline & Turkey $(\%) n=4855$ & Rural $(\%) n=1920$ & Urban $(\%) n=2935$ \\
\hline Individual reasons & & & 30.9 \\
Forgetting & 34.1 & 39.0 & 22.0 \\
Finding no time & 24.3 & 27.8 & 6.3 \\
Feeling no need & 6.8 & 2.7 & 2.6 \\
Adverse effect of the handwashing materials & 2.4 & & 29.8 \\
Environmental reasons & & 28.6 & 12.1 \\
Not to have right place or tap for handwashing & 29.4 & 9.2 & 12.7 \\
Lack of soap or other handwashing materials & 10.9 & 4.7 & 8.1 \\
Being the handwashing place not hygienic & 9.5 & 7.7 & \\
Being the place of lavatory not easily accessible & 8.0 & &
\end{tabular}

The percentages were calculated according to the numbers of answers divided to the total person number $(n)$. One person can give more than one answer

reasons, the $39.2 \%$ according to the environmental reasons, and the $7.5 \%$ of them according to the combined reasons are not washing their hands. Within the grouped not handwashing reasons, the frequency of the environmental reasons are highest in the urban citizens $(43.4 \%)$, in the highest education level $(55.5 \%)$. There is statistically significant difference between the groups in terms of age groups, educational level and settlement. $(p<0.001)$ (Table 4).

\section{Discussion}

\section{The change of handwashing frequency}

Handwashing frequency before the meals $(61 \%)$ found in our study is similar to results of some studies (for instance $53 \%$ in China and $73 \%$ in Korea) and the handwashing frequency before cooking (68\%) found in our study is higher than some of other studies (for instance $35 \%$ in Bangladesh and $42 \%$ in Kenya) [17, 31-33]. The handwashing frequency after the toilet in our study (91\%) is higher than most of similar studies. The frequencies in the studies change in a wide range (14-79\%) [17, 32-34].
Handwashing before cooking or meals have the equal threshold importance as the importance of handwashing after the toilet to prevent infectious diseases. In contrast, in our study, the frequencies of handwashing before cooking or meals are lower than the frequencies after the toilet, too, as in other studies [17,31-33]. This is also observed in the school health studies performed in Turkey [24, 26, 35]. An intervention for decreasing this difference might be suggested as emphasizing the fact that handwashing before the meals are as important as handwashing after the toilet in the training programs for development of handwashing.

Almost all (98.5\%) of the interviewed persons believes that the handwashing has a very high importance or high importance on preventing from the diseases. The difference between the frequencies of the attitudes preventing from the infectious diseases and some of the handwashing behaviors like the handwashing before the meals is also indicating the aspect between the attitudes according to the health behaviors and the practices of these behaviors in hand hygiene specialty. On the other hand, the high awareness level of the importance of the handwashing on the prevention from the infectious diseases can be determined as a convenient base for the activities according to the promotion of the handwashing. 
Table 4 The change of grouped not handwashing reasons according to some specifications

\begin{tabular}{|c|c|c|c|c|}
\hline & \multicolumn{3}{|c|}{ Grouped not handwashing reasons } & \multirow[t]{2}{*}{$p$} \\
\hline & Individual & Environmental & Combined & \\
\hline \multicolumn{5}{|l|}{ Age group } \\
\hline $12-20$ & 62.9 & 30.9 & 6.2 & $<0.001$ \\
\hline $21-30$ & 54.1 & 35.9 & 10.1 & \\
\hline $31-40$ & 49.6 & 43.3 & 7.0 & \\
\hline $41-50$ & 50.3 & 42.3 & 7.5 & \\
\hline $51-60$ & 48.9 & 43.8 & 7.3 & \\
\hline $61-70$ & 47.9 & 45.6 & 6.5 & \\
\hline $71-80$ & 61.4 & 33.5 & 5.1 & \\
\hline 81 and above & 62.2 & 28.9 & 8.9 & \\
\hline \multicolumn{5}{|l|}{ Sex } \\
\hline Female & 52.2 & 40.3 & 7.5 & 0.086 \\
\hline Male & 55.3 & 37.2 & 7.5 & \\
\hline \multicolumn{5}{|l|}{ Settlement } \\
\hline Rural & 58.4 & 32.7 & 8.9 & $<0.001$ \\
\hline Urban & 50.0 & 43.4 & 6.6 & \\
\hline \multicolumn{5}{|l|}{ Education level } \\
\hline No education & 63.2 & 30.1 & 6.7 & $<0.001$ \\
\hline $\begin{array}{l}\text { Primary } \\
\text { incomplete }\end{array}$ & 58.7 & 32.3 & 9.0 & \\
\hline $\begin{array}{c}\text { First level } \\
\text { primary }\end{array}$ & 52.1 & 39.8 & 8.1 & \\
\hline $\begin{array}{l}\text { Second level } \\
\text { primary }\end{array}$ & 60.2 & 33.6 & 6.2 & \\
\hline High school & 45.7 & 48.0 & 6.2 & \\
\hline $\begin{array}{l}\text { College/ } \\
\text { university }\end{array}$ & 34.8 & 55.5 & 9.7 & \\
\hline Total & 53.3 & 39.2 & 7.5 & \\
\hline
\end{tabular}

\section{Determinants of handwashing behavior}

It can be seen that the possibility of handwashing is higher in older ages in all of the linear and logistic regression models. Population-based study shows that older ages were protective factors for good hand hygiene [33]. It is remarkable that the handwashing frequencies both before the meals and after the toilet are low in 12-20 age group which includes adolescent period. This result has significance in country like Turkey having young population. 12-20 age groups are still a studying group, therefore the solution offered for that group should be made within the scope of the health promotion in the schools.

The implemented regression models show that women are more successful than men. In a number of studies, it is common that women have higher frequencies than men when handwashing is considered [17, 23, 33, 36-38]. It seems that structuring the health behaviors by gender roles reveals itself in determination of handwashing.

All three models in our study show that education level is determinant on handwashing. In other studies, it is indicated that handwashing is developed with increasing education level. [33, 39]. It is remarkable that, in studies conducted with students in Turkey, a positive relationship was found between handwashing and the education level of mother $[26,27]$. The results generally are indicating that the lower education levels shall be taken into consideration on the health promotion programs regarding the hand hygiene.

The linear regression constituted for HHS shows that the handwashing behavior is more developed in urban area. The fact that handwashing frequency for various situations is higher in urban area is indicated in other population based studies $[33,40]$. The effect of settlement on logistic regression model is not statistically significant for handwashing before the meals and after the toilet. This difference between the linear and logistic regression models points out that different patterns can be seen for handwashing behaviors in various situations.

\section{The change of not handwashing reasons}

The most frequent reasons for not handwashing is forgetting $(34.1 \%)$, not to have right place or tap for handwashing $(29.4 \%)$ and finding no time $(24.3 \%)$. The study results are limited for the reasons of not handwashing. According to a study in Korea, $39.6 \%$ of the survey respondents did not do so because they were 'not accustomed' to washing their hands and $30.2 \%$ thought that washing their hands is 'annoying' [17]. According to a study conducted with university students in Turkey, the main reason for skipping handwashing was the participants' belief of 'no need' $(63.7 \%)$ [23].

For all sub-groups, it is remarkable that the frequency of combined reason, including indicating at least one reason both individual and environmental, is $10 \%$ at most. The fact that people are grouped on either individual or environmental reasons results in two different targets in intervention attempts. In case of evaluation of HHS using a linear regression model, not handwashing frequency due to individual reasons is higher in disadvantageous group. According to this model not handwashing frequency due to environmental reasons is higher in advantageous groups. The groups having relatively lower handwashing frequencies seems to be benefiting from the intervention attempts aiming a change in behavior and the groups having relatively higher handwashing frequencies seems to be benefiting from the intervention attempts aiming to enhance the physical opportunities.

There is no limitation for the sanitation of the houses in Turkey, especially in urban areas. The percentage of 
population for the use of sanitation facilities in Turkey is $75 \%$ in rural areas and $97 \%$ in urban areas [41]. On the other hand, it is known that the handwashing availability increases with increasing socio-economic status [18, 22, 29]. In our study, while the handwashing habits are questioned, there was no discrimination between in the house and outside the house. In urban area and in high-educated groups, the fact that not handwashing frequency is higher due to environmental reasons might be the result of including the opinions of people about handwashing situations outside the house and in public places (work, restaurant, cafe, general toilets and so on). The decisiveness of the environmental conditions such as hygiene level and appropriateness of handwashing materials are mentioned in studies conducted in publicly available handwashing places $[38,42]$. The result of our study about the urban habitation areas gain significance since Turkey is a country progressing in urbanization process. The results of our study might be suggestive for other countries which still experience the urbanization processes.

The fact that not handwashing frequency is higher in people living in urban areas and in high-education groups might be the result of the relatively high expectancy of those groups about physical opportunities. When we consider all of them together, not handwashing might be related to a complex reasons network which is consisting of intertwining individual, socio-economic and environmental factors in different sub-groups with various weights. In a systematic review, it is mentioned about the hand hygiene improvement strategies, addressing only determinants such as knowledge, awareness, action control, and facilitation is not enough to change health behavior. Addressing combinations of different determinants showed better results [43]. According to a systematic literature review including 61 studies analyzing the interventions which used behavioral models in prevention of infectious diseases, most of the studies are related to individual-level theory; there is need for the evidences suggested by ecological-level change research [44]. The ecological health perspective helps to locate intervention points for promoting health by identifying multiple levels of influence on individuals' behavior and recognizing that individual behavior both shapes and is shaped by the environment [45]. The results of our study might contribute to the efforts of conceptualizing the health behaviors with ecological model.

\section{The limitations of the study}

The $63 \%$ of the interviewed persons are females, according to the profession breakdown, the people occupied with the house works are in the first line $49 \%$. This is probably due to including the people who were at home and accepted to participate in this study during data collection of the study. One of the limitations of this study is the questions are self-reported since when the case is handwashing, people might answer to the questions not with the real case but the case which they think it should be [17].

Conflict of interest There was no conflict of interest in this study.

\section{References}

1. http://www.who.int/healthinfo/global_burden_disease/GBD_report_2004update_full.pdf. Accessed 7 Jan 2015.

2. http://apps.who.int/iris/bitstream/10665/79200/1/9789241505239_ eng.pdf. Accessed 7 Jan 2015.

3. Carabin H, Gyorkos TW, Soto JC, Joseph L, Payment P, Collet JP. Effectiveness of a training program in reducing infections in toddlers attending day care centers. Epidemiology. 1999;10: 219-27.

4. Luby SP, Agboatwalla M, Feikin DR, Painter J, Billhimer W, Altaf A, et al. Effect of handwashing on child health: a randomised controlled trial. Lancet. 2005;366:225-33

5. Ejemot RI, Ehiri JE, Meremikwu MM, Critchley JA. Handwashing for preventing diarrhoea. Cochrane Database Syst Rev. 2008;23(1):CD004265.

6. Nicholson JA, Naeeni M, Hoptroff M, Matheson JR, Roberts AJ, Taylor D, et al. An investigation of the effects of a handwashing intervention on health outcomes and school absence using a randomised trial in Indian urban communities. Trop Med Int Health. 2014;19(3):284-92.

7. Azor-Martínez E, Cobos-Carrascosa E, Gimenez-Sanchez F, Martínez-López JM, Garrido-Fernández P, Santisteban-Martínez $\mathrm{J}$, et al. Effectiveness of a multifactorial handwashing program to reduce school absenteeism due to acute gastroenteritis. Pediatr Infect Dis J. 2014;33(2):e34-9.

8. White C, Kolble R, Carlson R, Lipson N, Dolan M, Ali Y, et al. The effect of hand hygiene on illness rate among students in university residence halls. Am J Infect Control. 2003;31(6): 364-70.

9. Rabie T, Curtis V. Handwashing and risk of respiratory infections: a quantitative systematic review. Trop Med Int Health. 2006;11(3):258-67.

10. Pickering AJ, Davis J, Blum AG, Scalmanini J, Oyier B, Okoth $\mathrm{G}$, et al. Access to waterless hand sanitizer improves student hand hygiene behavior in primary schools in Nairobi Kenya. Am J Trop Med Hyg. 2013;89(3):411-8.

11. Ray SK, Dobe M, Lahiri A, Basu SS. Hand washing practices in urban and rural communities in and around Kolkata, West Bengal. Indian J Public Health. 2009;53(3):192-5.

12. Greenland K, Iradati E, Ati A, Maskoen YY, Aunger R. The context and practice of handwashing among new mothers in Serang, Indonesia: a formative research study. BMC Public Health. 2013;13:830.

13. Person B, Schilling K, Owuor M, Ogange L, Quick R. A qualitative evaluation of hand drying practices among Kenyans. PLoS One. 2013;8(9):e74370. doi:10.1371/journal.pone.0074370.

14. Curtis VA, Schmidt W, Luby S, Florrez R, Toure O, Biran A. Hygiene: new hopes, new horizons. Lancet Infect Dis. 2011;11: 312-21.

15. Curtis V, Cairncross S, Yonli R. Domestic hygiene and diarrhoea-pinpointing the problem. Trop Med Int Health. 2000;5(1):22-32.

16. Rheinländer T, Thanh Xuan LT, Ngoc Hoat L, Dalsgaard A, Konradsen F. Hygiene and sanitation promotion strategies among 
ethnic minority communities in Northern Vietnam: a stakeholder analysis. Health Policy Plan. 2012;22(7):600-12.

17. Jeong JS, Choi JK, Jeong IS, Paek KR, In HK, Park KD. Nationwide survey on the handwashing behavior and awareness. J Prev Med Public Health. 2007;40(3):197-204.

18. Luby SP, Halder AK. Associations among handwashing indicators, wealth, and symptoms of childhood respiratory illness in urban Bangladesh. Trop Med Int Health. 2008;13(6):835-44.

19. Schmidt WP, Aunger R, Coombes Y, Maina PM, Matiko CN, Biran A, et al. Determinants of handwashing practices in Kenya: the role of media exposure, poverty and infrastructure. Trop Med Int Health. 2009;14(12):1534-41.

20. Halder AK, Tronchet C, Akhter S, Bhuiya A, Johnston R, Luby SP. Observed hand cleanliness and other measures of handwashing behavior in rural Bangladesh. BMC Public Health. 2010;10:545.

21. Park JH, Cheong HK, Son DY, Kim SU, Ha CM. Perceptions and behaviors related to hand hygiene for the prevention of H1N1 influenza transmission among Korean university students during the peak pandemic period. BMC Infect Dis. 2010;10:222.

22. Çetinkaya S, Arslan S, Nur N, Demir ÖF, Özdemir L, Sümer H. Sivas il merkezi'nde sosyoekonomik düzeyi farklı üç ilköğretim okulu öğrencilerinde kişisel hijyen alışkanlıkları. Süreli Tıp Eğitimi Dergisi. 2005;14(10):229-36.

23. Ergin A, Bostanci M, Onal O, Bozkurt AI, Ergin N. Evaluation of students' social hand washing knowledge, practices, and skills in a university setting. Cent Eur J Public Health. 2011;19(4):222-6.

24. Altun I, Cinar ND, Dede C. Hygiene behaviour in university students in Turkey. J Pak Med Assoc. 2013;63(5):585-9.

25. Önsüz MF, Hıdıroglu S. Determining personal hygiene practices of students in two different primary school in İstanbul. J Adnan Menderes Univ Med Fac. 2008;9(1):9-17.

26. Şimşek Ç, Piyal B, Tüzün H, Çakmak D, Turan H, Seyrek V. Personal hygiene behavior of some high school students in Ankara province. TAF Prev Med Bull. 2010;9(5):433-40.

27. Kaya M, Büyükşerbetçi M, Meriç MB, Çelebi AE, Boybeyi Ö, Işık A, et al. Ankara'da bir lisenin 9 ve 10. sinif öğrencilerinin kişisel hijyen konusunda davranişlarinin belirlenmesi. Sürekli Tıp Eğitimi Dergisi. 2006;15(10):179-83.

28. Arıkan D, Özkan H. Knowledge and applications about hand hygiene of the mothers. TAF Prev Med Bull. 2011;10(5):573-8.

29. Ocaktan ME, Baran E, Akdur R. Evaluation of habitual behaviour related to genital hygiene in women living in a health care center area. Saudi Med J. 2010;31(11):1251-6.

30. Üner S, Sevencan F, Başaran E, Balcı C, Bilaloğlu B. To determine some knowledge and attitudes related to the social hand washing of individuals who apply to a primary health center. TAF Prev Med Bull. 2009;8(3):207-16.
31. Ray SK, Zaman FA, Laskar NB. Hand washing practices in two communities of two states of eastern India: an intervention study. Indian J Public Health. 2010;54(3):126-30.

32. Aunger R, Schmidt WP, Ranpura A, Coombes Y, Maina PM, Matiko CN, et al. Three kinds of psychological determinants for hand-washing behaviour in Kenya. Soc Sci Med. 2010;70(3): 383-91.

33. Tao SY, Cheng YL, Lu Y, Hu YH, Chen DF. Handwashing behaviour among Chinese adults: a cross-sectional study in five provinces. Public Health. 2013;127(7):620-8.

34. http://apps.who.int/gho/data/node.main.169?lang=en. Accessed 5 Oct 2014.

35. Güleç M, Topbaş M, Kır T, Hasde M. The habit of handwashing among the students chosen from two districts at Ankara which have different socioeconomic levels. Turk Hij Den Biyol Derg. 2000;57(2):71-6.

36. Johnson HD, Sholcosky D, Gabello K, Ragni R, Ogonosky N. Sex differences in public restroom handwashing behavior associated with visual behavior prompts. Percept Mot Skills. 2003;97:805-10.

37. Garbutt C, Simmons G, Patrick D, Miller T. The public hand hygiene practices of New Zealanders: a national survey. N Z Med J. 2007;120(1265):U2810.

38. Mariwah S, Hampshire K, Kasim A. The impact of gender and physical environment on the handwashing behaviour of university students in Ghana. Trop Med Int Health. 2012;17(4):447-54.

39. Luby SP, Halder AK, Tronchet C, Akhter S, Bhuiya A, Richard BJ. Household characteristics associated with handwashing with soap in rural Bangladesh. Am J Trop Med Hyg. 2009;81(5): $882-7$.

40. Ray SK, Dobe M, Maji S, Chakrabarty D, Sinha Roy AK, Basu SS. A pilot survey on hand washing among some communities of West Bengal. Indian J Public Health. 2006;50(4):225-30.

41. http://www.wssinfo.org/fileadmin/user_upload/resources/JMP-report 2014Table_Final.pdf. Accessed 7 Jan 2015.

42. Norris P, Choi T, Lee R, Lu A, Png C, Yang S. Adequacy of handwashing facilities in public toilets in Dunedin, New Zealand. Aust N Z J Public Health. 2012;36(2):194-5.

43. Huis A, van Achterberg T, de Bruin M, Grol R, Schoonhoven L, Hulscher M. A systematic review of hand hygiene improvement strategies: a behavioural approach. Implement Sci. 2012;7:92.

44. http://www.ecdc.europa.eu/en/publications/Publications/healthcommunication-behaviour-change-literature-review.pdf. Accessed 5 Oct 2014.

45. Fertman CI, Allensworth DD, Elaine AM. What are health promotion programs? In: Fertman CI, Allensworth DD, editors. Health promotion programs: from theory to practice. The Society for Public Health Education. USA: 2010. p. 3-28. 